\title{
Collusion and bid rigging in the construction industry: case studies from Poland
}

\author{
Andrzej Foremny ${ }^{\mathrm{a}}$, Janusz Kulejewski ${ }^{\mathrm{a}}$, Hubert Anysz ${ }^{\mathrm{a}}$ Aleksander Nicał ${ }^{\mathrm{a}}$ \\ ${ }^{a}$ Warsaw University of Technology, Plac Politechniki 1, Warsaw 00-661, Poland
}

\begin{abstract}
Polish economy experienced significant changes during the past 30 years. System transformation that began in the 1980's and was enhanced by Poland's entry to the European Union in 2004 significantly influenced economic development. Apart from tough history experiences, they formed the shape of national economy which can be observed nowadays. It was a long and difficult process. During political and economic rapid changes greater numbers of price collusions and other illegal practices can be observed than during the stable development of national economy. Authors selected and reviewed the most important anti-competitive cases in the construction industry from the past 30 years in Poland. The review includes not only cases that were officially justified and penalized - like the collusion of portland cement big producers - but also cases of collusion suspicion on highway and express roads that ended with acquittal court verdicts.
\end{abstract}

(C) 2018 The Authors. Published by Diamond Congress Ltd., Budapest University of Technology and Economics Peer-review under responsibility of the scientific committee of the Creative Construction Conference 2018.

Keywords: bid rigging ; case study ; cement cartel ; collusion ; collusion detection ; highway ; public tender ; road;

\section{Introduction}

Anti-competitive agreements are not a new practice in economy. The idea of price fixing performed by producers is simple and was already present in antiquity. Since ages, there have been attempts to establish laws and codification rules, which were to assure fair regulation of production rules and price fixing on the market. The oldest known case of an anti-competitive agreement [1] is the price fixing of Athenian grain importers in $388 \mathrm{BC}$. The problem of collusion and bid rigging has been a subject of many studies, i. a. [2-10]. Construction industry, including road construction is an important and capital-consuming branch of world economy. The authors want to strongly emphasize that the evaluation of collusion occurrences recalled in this paper is based strictly and limited to publicly available documents: court verdicts, prosecutor's investigation data and public tender announcements. The authors by no means express personal judgement concerning collusion occurrence.

\section{Price fixing among cement producers}

Cement industry is characterised by little flexibility among cement buyers. Consequently, the rise of cement prices usually does not cause consignees to purchase substitutes, for there is no such substitute with identical properties as cement which could replace it as a component in concrete production. Price increase in sales of cement significantly influences the price of concrete. However, it does not cause a relevant change in concrete and cement demand. The market is dominated by large cement producers. The manufactured product is homogenous and undergoes periodic laboratory testing in order to maintain its performance properties required by law. The possibility of new enterprises entering the market is hugely restricted due to necessary significant expenditure towards production machines and due 
to the limited access to raw materials. All above mentioned reasons lead to a tendency among producers to establish anti-competitive agreements, in particular recurrent collusions [11], irrespective of a country, political system and existing legislation. The number of producers usually remains the same before and after the time of collusion. It is confirmed by multiple cases of global infringements and cement cartels operating in Poland during the interwar period, at the end of 1980s and in the years 1998-2009.

Cement industry in Poland has undergone substantial changes in the 1990s. Its privatisation took place at the beginning of political transformation and the biggest international companies such as Lafarge, Heidelberg, Dyckerhoff, $\mathrm{CRH}$, Miebach and RMC became operational on the market. In the following years, these companies consequently strengthened their market position through methodical takeovers and restructuration of acquired plants. Before the transformation, there were at least 21 existing cement plants on the Polish market. As a result of the consolidation of the sector and the transformations performed inside corporate groups, there were at least 13 already existing cement plants and 1 newly launched on the national market in 2006. A significant number of closed plants possessed overexploited manufacturing elements and their production capacity was noticeably low. These are some of the reasons why new investors decided to either close or convert them into transhipment terminals. The modernization would have been not cost-effective. The political transformation led to a change in the legal rules of cooperation among cement producers in Poland. As a result of privatisation processes, large international companies took ownership of Polish enterprises and became competing entities in the realm of free-market economy.

The transformation process had an impact also on Polish associations comprising companies from cement and limestone industry. Such associations had existed on the market under different brand names since many years: The Cement, Limestone and Gypsum Industry Association (until July 1982), The Binding Construction Materials Industry Enterprises Association and The Cement and Limestone Producers Association, which in June 2005 changed its name into The Cement Producers Association [SPC]. All enterprises participating in the cement collusion of 1998-2009 were members of SPC. As history has shown, most cement producers decided to prevent or minimalize the results of their own financial deterioration in the view of transformation and returned to the centrally planned economy period's status quo of price fixing and manipulation of economic activities.

According to The Office of Competition and Consumer Protection [UOKiK], "The President of the Office has found that the largest cement producers in Poland have been dividing the market at least since 1998, fixing permitted shares for respective entities, as well as prices of cement, levels of price increases along with their dates and order of introduction. For this purpose, they shared confidential information, i.a. on the volume of completed sales. The fixing was being performed on numerous meetings, both multi-and bilateral, at the level of board chairmen and commercial directors. The investigation showed that even if not all cartelists were present at a meeting, decisions were being conveyed to those absent. There was an established coordinator who exchanged information relevant for the cartel functioning with designated representatives of other cement plants. Cases of pursuing individual sale policies or misleading other members of this illegal agreement also appeared during the long-time cartel existence. However, such attempts were being immediately condemned and severely punished by the collusion parties". As shown in the above mentioned quote, the mechanism of illegal fixing was professionally organised. Public services could not find any hard evidence based on phone records, for cement producers' telephone contacts (some of which made from separate pre-paid mobile phones) were in principle limited only to agreeing on the meeting point. The entrepreneurs were brought down during the police raid whatsoever. It was discovered that the conspirators named themselves (sic!) 'Group G7'. Case evidence included i.a. tables, spreadsheets and paper notes found during the inspection in the companies' headquarters [12,13].

A pure coincidence contributed to the collusion exposure. In 2005, during the distribution of greenhouse gases emission allowances performed by the Ministry of the Environment, it was discovered that levels of actual cement production were much higher than it followed from data delivered by the producers. Mutual deceit within the "Group G7" was the cause of these differences: Cemex lowered its actual cement production level by ca. 0,6 million tonnes. Literature indicates that cartels are by its very nature unstable, because of permanently occurring incentives leading to inside deceit among the parties. In practice, deceit is an inherent feature of cartel operation. Entrepreneurs, who establish and then break anti-competitive agreements are often likely not to abide by reciprocal deals. It is worth mentioning that the extent of Cemex's underestimation equalled to ca. 4,76 \% of the entire cement production in Poland in 2005 - which is a relatively high number. Other cartelists were "honest" among "Group G7" at least in this aspect, namely, they delivered actual data concerning levels of sold cement. The cement cartel was well organised. Cemex's underestimation of data regarding cement production triggered the necessity of punishment for this entity imposed by other collusion members, and future compensation for the damages suffered so far. Calculations and simulations were performed. Consequently, after negotiations, an agreement was reached, pursuant to which Cemex must have lowered 
its sell and declared an increase of prices. The cooperation within cement cartel was not only about the exchange of information. It was a meticulously planned, long-term process, lasting at least since 1998, and its inherent part was an attempt to permanently stabilize the shares of individual entrepreneurships existing on the market. The establishment of particular shares for each collusion member occurred through references to 'historic' quotas of cement production of individual producers in the times of centrally planned economy.

The period of cement collusion in Poland can be divided into another two periods. Period 1 (lasting until the end of 2002), when the entrepreneurs exchanged information among each other through The Cement Producers Association, being in a sense the continuation of the pre-transformation system. Period 2 (after 2002), when economic information was not conveyed to SPC, but rather to an outside party bound by confidentiality provisions: The Law and Industrial Property Office 'Optimas'. The hiring of an outside entity was expected to create a formal structure, compliant with the competition law. In reality, there was also an existing "parallel system". The exchange of information among members of the cartel was happening at two levels. Firstly, within the law, through The Office 'Optimas'. Secondly, and unlawfully, through SPC or directly among each other. Coordinators responsible for the information exchange were being nominated from each entity and they were being frequently replaced.

The UOKiK decision provides information on some of the procedures of services concerned with economic crime detection. Operational swiftness and effective coordination are very important factors allowing for securing evidence which directly points towards anti-competitive malpractices. In the discussed case, some details suggesting the prevalence of collusion, such as e.g. additional notes found alongside certain columns, the dates of file modification or the occurrence of the name "Group G7" proved to be essential for the investigation. During UOKiK's inspection in the Ożarów Group headquarters, representatives of the Office found direct evidence of collusion. It was a protocol of the meeting of the Group Board, in which a following statement was found: "There is a chance of increasing the prices in the next year's first quarter. However, talks on the executive level of individual groups are needed" [12]. Such a document was introduced in the Group's headquarters in Warsaw and became missing shortly after. A separate group of UOKiK's officials was in control of the second headquarters of this group in Karsy town but the above mentioned quote was not found in protocols there. The Office found that the Board Office Manager had hidden the page with controversial notes, then edited the file in the computer by deleting the notes and introduced the printed protocol as complete. After a police technician performed an 'undo' procedure in the open file, the previously deleted notes appeared again. This example proves how important is quick and unannounced action during investigations run by antitrust services and offices. The employees, faced with stress related to the investigation process, may get caught off guard and deliver sensitive documents which might be impossible to retrieve at a later stage.

As a consequence of exposing the collusion, cement producers were financially penalised with fines amounting to PLN 339 million. Levels of the fines for individual cartel members oscillate between 5 to $10 \%$ of the revenue figure of the penalised company from one year preceding the collusion exposure. The collusion lasted for at least 12 years. The cement industry revenue figures in Poland from 2007 amount to PLN 6,8 billion, with a total production at a level of 17 million tonnes and a price of PLN 400. This implies that if cement prices had been extortionate by $10 \%$, the estimated loss of consignees in the twelve-year period of competition law infringement might have equalled to ca. PLN 8,2 billion.

\section{Suspected bid rigging in road construction industry}

Social and economic fallout of bid rigging in road construction is particularly dangerous for the society because of the induced deadweight losses of large size. Anti-competitive actions of these agreements' members always lead to price increase in road building. However, in case of the roads of significant importance for the country, was the collusion to remain unproven, the suspicion itself might bring higher social and economic losses than the sheer existence of undetected collusion. Whenever the road is built and made available within deadlines, the society is financially disadvantaged only in terms of the contract prices being higher than on the not abused market. Conversely, in the event of collusion suspicion and a long term investigation (or an investigation closure due to lack of evidence), social and economic costs might bring more harm upon both public treasury and individuals.

\subsection{Expansion of national road 8 on the stretch Jeżewo-Bialystok (collusion suspicion)}

The results of the tender 'Expansion of national road 8 to the two-lane expressway parameters on the stretch Jeżewo - Bialystok' were announced on June $6^{\text {th }}, 2009$. The winner was a consortium of companies: Mota Engil, Strabag and Transprojekt Gdański, with an offered price of PLN 675 million gross. The runner-up was the consortium of Mostostal, 
Budimex-Dromex, Bilfinger Berger and Arcadis, offering a price of PLN 699,2 million gross. The third and last competitor was the consortium of PBDiM Mińsk Mazowiecki, Astaldi and Dro-consult, offering a price of PLN 703,4 million. The Internal Security Agency [ABW] suspected the occurrence of an agreement upon the offered prices during the bidding process. Recorded phone calls of the companies' managers, which implied colluding in a verbal code, were to be used as evidence. According to ABW, repeated references of "room 698" made by Strabag's director in the recorded phone calls indicated that the offer of Mostostal and Budimex Dromex consortium could not have been lower than PLN 698 million in order to enable the win of Strabag's consortium. In exchange for such agreement, the above mentioned consortium was expected to win the tender for the reconstruction of national road 8 on the stretch Piotrków Trybunalski - Rawa Mazowiecka [14]. The accused companies did not agree with the lawsuit's contents. The court acquitted all 11 defendants. The prosecutor appealed against the sentence but it was overruled $[15,16]$. Eventually, GDDiKA withdrew the lawsuit.

\subsection{Expansion of national road 8 on the stretch Piotrków Trybunalski - Rawa Mazowiecka (collusion suspicion)}

The results announcement of the tender for a state contract 'Design and expansion of national road 8 to the twolane expressway parameters on the 61 kilometres long stretch Piotrków Trybunalski - Rawa Mazowiecka' took place on March $17^{\text {th }}$, 2009. The winner was a consortium of companies: Astaldi, PBDiM Mińsk Mazowiecki, PBDiM Erbedim, Intercor and Technital with an offer of a gross value of PLN 1734 million. Second place belonged to the consortium comprised of Budimex-Dromex, Mostostal Warszawa, Bilfinger Berger and Arcadis, offering a gross price of PLN 1771 million. The third and last bidder was a consortium of entities from the corporate group named Strabag, Mota Engil Poland and Transprojekt Gdańsk with a gross price of PLN 1910 million but this offer was rejected by the ordering party due to inconsistencies with Terms of Reference. It was found during the investigation (based on The Internal Security Agency [ABW] surveillance) that Mostostal might have acquired information about the tender details from the director of the Warsaw department of General Director for National Roads and Motorways (GDDKiA). The information might have been passed to the consortium members. Transcripts from the recorded phone calls indicate that values of the offers might have been agreed upon among the companies beforehand. However, after the opening of the envelopes it became clear that the winning consortium was the one with Astaldi (theoretically not participating in the collusion). According to the media reports, the winning consortium ordered phone surveillance from an outside provider on its own member: Erbedim, suspecting it of collusion with another consortium. According to the phone transcripts, an offer price of PLN 1860 million gross was established within the consortium led by Astaldi. This information was passed to Mostostal by the director of Erbedim which might have enabled the offer adjustment. Astaldi, suspecting the leak, lowered the price to PLN 1734 million gross, not notifying Erbedim, and won the tender, which came as a surprise for the second in line consortium and Erbedim itself [17,18]. After the announcement of the tender results, the companies decided to create no more consortia in the existing configuration. For the tender was won by another consortium (unsuspected of bid rigging), new opinions appeared, stating that the companies' foreign headquarters communicate within the highest ranks, irrespective of Polish managers [19].

At the end of 2016 GDDiKA filed a lawsuit against Budimex Dromex, Mostostal Warszawa and Bilfinger Berger. GDDiKA demanded PLN 539,9 million by way of compensation for the usage of prohibited 'concerted practice', meaning 'the replacement of autonomous economic decisions with arrangements performed within competing entities submitting biddings for the same public tender' [20]. The accused companies did not agree with the lawsuit's contents. The court acquitted all 11 defendants. The prosecutor appealed against the sentence, but it was overruled $[15,16]$. Eventually, GDDiKA withdrew the lawsuit.

\subsection{Construction of motorway A4 Radymno-Korczowa (collusion suspicion)}

On September $7^{\text {th }}, 2009$ the opening of envelopes with bidding offers concerning the contract 'Design and construction of motorway A4 Rzeszów - Korczowa on the 22-kilometer stretch Radymno (without the hub) - Korczowa' took place. The tender was won by a Greek company J\&P Avax, which submitted an offer of PLN 818, 5 million gross with a 120-months warranty and the expiry date of the tender validity period set for $30^{\text {th }}$ April, 2012. According to ABW, it might have been a case of anti-competitive agreement between Strabag and its competitors: MSF Polska, Autostrada Wschodnia, Mostostal Warszawa, Budimex-Dromex and DTP Terrassement. The collusion expected all offers to be no higher than PLN 951 million and the process of misinforming the ordering party about the prices included in offers. The accused companies did not agree with the lawsuit's contents. The court acquitted all 11 
defendants. The prosecutor appealed against the sentence but it was overruled $[15,16]$. Eventually, GDDiKA withdrew the lawsuit.

\subsection{Construction of junction between motorway A4 (Krzyż hub) with regional road 977 (collusion confirmed with a court sentence)}

The results of the public tender concerning 'Construction of junction between motorway A4 (Krzyz hub) with regional road 977' were announced in 2010. The winner was a consortium of companies: Mota Engil, Strabag and Poldim. The investment was finalised in 2012 and cost PLN 41,5 million. Following its completion, an investigation was pursued. It was concluded that a collusion between competitors had occurred and the case was referred to the court [21]. In the meantime, the city of Tarnów must have returned PLN 14 million of the European Union grant due to the risk of the necessity to return the entire sum. The suspicion of collusion arose whilst investigating another investment: the construction of a tram line in Cracow. It was the information provided by one the collusion members who offered his testimony in exchange for an extraordinary mitigation of punishment [22] that proved decisive for exposure and resolution of the case. It was established during the investigation that three of the consortium members came into agreement with their competitors. Pursuant to the agreement, they were expected to either submit much higher price offers or withdraw from the tender [23]. Individuals from the ordering party - Tarnów Public Transport Authorities, closed in January 2012 - also participated in the collusion. The anti-competitive agreement entered into force and its members exchanged illegally acquired funds among each other. The fiscal control showed that the legalisation of the funds was performed through issuing invoices for fictitious services or fake construction protocols. Performed analysis and expertise estimated that the ordering party suffered losses of PLN 25,8 million (the amount of the winning bid overestimation) as a result of the collusion. In 2016, a settlement was reached. Mota Engil and Strabag agreed to pay PLN 31,7 million to Tarnów City County by way of compensation. In May 2016, The District Court sentenced 14 defendants of this case to suspended detention and heavy fines. In another legal proceedings of the same case, The Regional Court sentenced ex-president of Tarnów for corruption and abuse of power to five years of detention, tenyear prohibition for holding executive positions in local authorities and a fine of PLN 295000 by way of compensation to the city.

\subsection{Construction of motorway Al Częstochowa - Pyrzowice, stretch H (collusion suspicion)}

The tender results of a contract for 'Construction of motorway Al Tuszyn - Pyrzowice, stretch H, Zawodzie hub (without the hub) - Woźniki (hub included)' were announced in February 2015. After the opening of the envelopes, the tender committee declared that the cheapest offer of PLN 532,8 million gross was submitted by Intercor. The winner did not provide a deposit and did not prolong the tender validity period, therefore it was excluded from the competition whatsoever. What is more, six other companies were excluded from the tender and their offers rejected. In result, the subsequent offer was chosen - a consortium of two companies from the Strabag corporate group, offering a price of PLN 574,5 million gross. GDDiKA suspected a bid rigging agreement between the competitors and the case was presented to the prosecution [24]. Eventually, the investigation was dropped on account of the lack of data proving the commitment of a crime [25].

\subsection{Construction of the bypass of Olsztyn (collusion suspicion)}

The tender results of a project 'Construction of S51 Olsztyn - Olsztynek on the stretch Olsztyn East - Olsztyn South' were announced in April 2015. After the opening of the envelopes, the tender committee declared that the cheapest offer of PLN 548,9 million gross was submitted by Bilfinger [25]. The winner did not provide a deposit, hence it was excluded from the competition. The subsequent offer (the consortium of companies Intercor and Most) was rejected due to the lack of consistency with the specification. The offer third in line (the consortium of companies Salini, Todini and PBDiM Kobylarnia) was found abnormally low and rejected. Salini filed an appeal to The National Appeals Chamber (KIO) but the appeal was rejected as well [24]. Ultimately, the winner of the tender was Budimex with an offer of PLN 913 million gross. The investigation was eventually dropped due to the lack of data proving the commitment of a crime [25]. 


\subsection{Extension of national road 8 on the stretch Przeszkoda-Radziejowice (collusion suspicion)}

The full name of this contract is 'Extension of national road 8 to the two-lane expressway parameters on the stretch from the hub with the voivodeship road 579 in Radziejowice to the hub with voivodeship road 721 in Wolica; Task I: the project continuation and expansion of national road 8 to the two-lane expressway parameters on the 9,9 kilometres long stretch Radziejowice - Przeszkoda'. After the opening of the envelopes, the tender committee declared that the cheapest offer of PLN 306,9 million gross was submitted by Strabag [24]. In this competition there were also other participating companies: Bilfinger, Mirbud, Mostostal Kraków, Metrostav and Gulermak. The tender for the adjoining stretch Przeszkoda - Paszków was won by Intercor (offer of PLN 436,7 million gross), whilst neither Strabag nor Budimex participated in this tender [24]. The investigation was eventually dropped due to the lack of data proving the commitment of a crime [25].

\subsection{Construction of the bypass of Góra Kalwaria along national roads 50/79 (collusion suspicion).}

After the opening of the offers, the tender committee declared that the cheapest offer of PLN 267, 8 million gross was submitted by Bilfinger [24]. The winner did not prolong the period of deposit validity, hence was excluded from the competition and the consortium of companies Intercor and Planeta took its place with an offer of PLN 313,7 million gross. Mirbud, in third place and with an offer of PLN 329,0 million gross filed an appeal to the National Appeals Chamber. The Chamber recognised the appeal and rejected the winning offer of Intercor and Planeta. However, the rejected competitor filed a complaint to the District Court, which found the complaint legitimate and substantiated. The investigation was eventually dropped due to the lack of data proving the commitment of a crime [25].

\subsection{Summary}

The above mentioned cases of contracts suspected of bid rigging became the subject of three bigger, separate court or prosecution proceedings. The first investigation dealt with tenders related to national road 8 on the stretches JeżewoBiałystok and Piotrków Trybunalski-Rawa Mazowiecka. In accordance with the existing laws, an exposure of price collusion might be a basis for withholding or withdrawing of public funding obtained also from European Union grants, irrespective of the ordering party's participance in such practices. As a result of an investigation led by ABW, European Commission withheld the PLN 3,5 million subsidy payment until the investigation would have become dropped. It is a particularly interesting case in the light of likelihood that one of the members of the collusion (Erbedim) was passing information to the competing consortium $[14,17,18]$. Hypothetically, it may have caused the failure of the collusion, hence proving its existence became impossible (lack of the losses on the side of ordering parties). Differences between the prices known from the recorded phone calls and the factual submitted offers (even though relatively small) were another factors indicating the lack of collusion. The second investigation was related to motorway A1 Częstochowa Pyrzowice on the stretch $\mathrm{H}$, the bypass of Olsztyn, national road 8 on the stretch Przeszkoda-Radziejowice and the bypass of Góra Kalwaria. On the grounds of the collusion suspicion, the prosecution started an investigation which was later dropped due to the lack of evidence justifying the suspicion of crime commitment. The third investigation concerned only one tender related to the junction of motorway A4 and voivodeship road 977. (Only this investigation can be acknowledged as a proven case of bid rigging, as only in this case the acquired evidence allowed for a conviction rendered by the court. Comparison of the case studies was presented in table 1 below.

Table 1. Comparison of selected public tenders for road construction in Poland 2009-2017

\begin{tabular}{lllll}
\hline $\begin{array}{l}\text { Selected road tenders announced } \\
\text { between 01.01.2009 and } \\
\text { 30.06.2017 in Poland }\end{array}$ & $\begin{array}{l}\text { Collusion } \\
\text { existence }\end{array}$ & $\begin{array}{l}\text { Winning } \\
\text { company/consortium }\end{array}$ & $\begin{array}{l}\text { Why collusion was } \\
\text { suspected }\end{array}$ & How the case finished \\
\hline $\begin{array}{l}\text { Expansion of national road } 8 \text { on } \\
\text { the stretch Jeżewo-Białystok }\end{array}$ & $\begin{array}{l}\text { Collusion } \\
\text { suspicion }\end{array}$ & $\begin{array}{l}\text { Mota Engil, Strabag } \\
\text { and Transprojekt } \\
\text { Gdański }\end{array}$ & $\begin{array}{l}\text { Recorded phone } \\
\text { calls of managers }\end{array}$ & $\begin{array}{l}\text { Court acquittal, appellation } \\
\text { overruled, lawsuit withdrawn }\end{array}$ \\
$\begin{array}{l}\text { Expansion of national road } 8 \text { on } \\
\text { the stretch Piotrków Trybunalski } \\
\text { - Rawa Mazowiecka }\end{array}$ & $\begin{array}{l}\text { Collusion } \\
\text { suspicion }\end{array}$ & $\begin{array}{l}\text { Astaldi, PBDiM Mińsk } \\
\text { Mazowiecki, Erbedim, }\end{array}$ & $\begin{array}{l}\text { Recorded phone } \\
\text { calls of managers }\end{array}$ & $\begin{array}{l}\text { Court acquittal, appellation } \\
\text { overruled, lawsuit withdrawn }\end{array}$ \\
$\begin{array}{l}\text { Construction of motorway A4 } \\
\text { Radymno-Korczowa }\end{array}$ & $\begin{array}{l}\text { Collusion } \\
\text { suspicion }\end{array}$ & J\&P Avax & $\begin{array}{l}\text { Recorded phone } \\
\text { calls of managers }\end{array}$ & $\begin{array}{l}\text { Court acquittal, appellation } \\
\text { overruled, lawsuit withdrawn }\end{array}$
\end{tabular}




\begin{tabular}{|c|c|c|c|c|}
\hline $\begin{array}{l}\text { Construction of junction between } \\
\text { motorway A4 (Krzyż hub) with } \\
\text { regional road } 977\end{array}$ & $\begin{array}{l}\text { Collusion } \\
\text { confirmed }\end{array}$ & $\begin{array}{l}\text { Mota Engil, Strabag } \\
\text { and Poldim }\end{array}$ & $\begin{array}{l}\text { Connection to other } \\
\text { investigation and } \\
\text { confession of } \\
\text { collusion member }\end{array}$ & $\begin{array}{l}\text { Court convictions to } \\
\text { suspended detention and } \\
\text { heavy fines }\end{array}$ \\
\hline $\begin{array}{l}\text { Construction of motorway A1 } \\
\text { Częstochowa - Pyrzowice, } \\
\text { stretch H }\end{array}$ & $\begin{array}{l}\text { Collusion } \\
\text { suspicion }\end{array}$ & Strabag & $\begin{array}{l}\text { Rejection of } 7 \text { offers } \\
\text { including the initial } \\
\text { winner }\end{array}$ & $\begin{array}{l}\text { The investigation dropped due } \\
\text { to lack of collusion evidence }\end{array}$ \\
\hline $\begin{array}{l}\text { Construction of the bypass of } \\
\text { Olsztyn }\end{array}$ & $\begin{array}{l}\text { Collusion } \\
\text { suspicion }\end{array}$ & Budimex & $\begin{array}{l}\text { Rejection of first } 3 \\
\text { offers }\end{array}$ & $\begin{array}{l}\text { The investigation dropped due } \\
\text { to lack of collusion evidence }\end{array}$ \\
\hline $\begin{array}{l}\text { Extension of national road } 8 \text { on } \\
\text { the stretch Przeszkoda - } \\
\text { Radziejowice }\end{array}$ & $\begin{array}{l}\text { Collusion } \\
\text { suspicion }\end{array}$ & Strabag & $\begin{array}{l}\text { Not natural offerors } \\
\text { behavior on adjacent } \\
\text { road tenders }\end{array}$ & $\begin{array}{l}\text { The investigation dropped due } \\
\text { to lack of collusion evidence }\end{array}$ \\
\hline $\begin{array}{l}\text { Construction of the bypass of } \\
\text { Góra Kalwaria along national } \\
\text { roads } 50 / 79\end{array}$ & $\begin{array}{l}\text { Collusion } \\
\text { suspicion }\end{array}$ & Intercor and Planeta & $\begin{array}{l}\text { Rejection of the } \\
\text { winning offer }\end{array}$ & $\begin{array}{l}\text { The investigation dropped due } \\
\text { to lack of collusion evidence }\end{array}$ \\
\hline
\end{tabular}

The introduced cases of public tenders in the Polish road construction industry prove that swift exposure and proof of bid rigging is difficult. Acquiring direct and hard evidence of collusion is even more difficult, regardless of phone surveillance and other operational techniques. Out of 8 examined contracts suspected of anti-competitive collusion, only once the collusion was confirmed by a court sentence, which allowed for punishment of its members and damage payments towards the ordering party (table 2). In the remaining 7 cases, relevant public services performed investigations and did not find any bid rigging occurrences.

Table 2. Summary of number of public tenders for road construction suspected for collusion in years 2009-2017

\begin{tabular}{lll}
\hline & Number of tenders (pcs) & Part of total (\%) \\
\hline Estimated total number of tenders (value higher than PLN 10 000 000) & $>=1000$ & $100 \%$ \\
Free from collusion suspicion & 992 & $99,2 \%$ \\
Collusion suspicion but not proven & 7 & $0,7 \%$ \\
Collusion confirmed and proven by court sentence & 1 & $0,1 \%$ \\
\hline
\end{tabular}

\section{Other cases of price collusions - Oriented Strand Boards, gutters, aggregate}

Another example of the infringement of competition law is an agreement between producers of particle boards and fiberboards used in construction: Kronospan Szczecinek, Kronospan Mielec, Pfleiderer Group, Pfleiderer Group, Pfleiderer Wieruszów and Swiss Krono [26]. During the investigation proceedings, UOKiK concluded that above mentioned entrepreneurs colluded on price fixing and the exchange of commercial information (dates of price hikes, revenue figures) regarding wood-based panels. On December $21^{\text {th }}, 2017$ UOKiK issued a decision recognising such practices lasting until September $9^{\text {th }}, 2011$ as anti-competitive and imposed fines [27]. The usage of the punishment mitigation programme by Swiss Krono contributed to the exposure of collusion as it simplified the process of gathering strong evidence of verbal price fixing and information exchange.

Based on the media reports, it may be concluded, that in the period of last several years in Poland there were other cases of infringement or alleged infringement of competition laws among following group of entrepreneurs: aggregate and asphalt suppliers, gutter and abrasives producers $[28,29]$ and other construction materials suppliers.

\section{Summary and conclusions}

The authors of this paper conducted a review with regard to cases of suspected anti-competitive practice and cases confirmed by court sentences. Effective exposure and penalisation of such practices is difficult and requires swift and coordinated action. There is no one universally-applicable method. Combinations of various methods prove most successful, i.a. scientific and economic studies [30], artificial intelligence [6-8], statistical analysis, hard evidence (e.g. wiretapping and surveillance), demonstrating factual losses of ordering parties, 'leniency' programmes.

Existing market environment, concentrations between undertakings, type of activity, as well as economic transformations, large events affecting the demand for quick infrastructure expansion (e.g. accumulation of EU aid schemes or organisation of global sports events) - all these influence the possibility of anti-competitive agreements. 
The lack of providing effective proof of bid rigging in road construction industry, which is a subject of this paper, does not have to mean that the price collusion did not appear at all.

\section{References}

[1] S.C. Todd, The Shape of Athenian Law, Oxford Univ. Press Inc. (1993).

[2] R.H. Porter, J.D. Zona, Detection of Bid Rigging in Procurement Auctions, J. Polit. Econ. 101 (1993) 518-538. doi:10.1086/261885.

[3] J.E. Harrington Jr., Behavioral screening and the detection of cartels, Eur. Compet. Law Annu. (2006).

[4] I. Morozov, E. Podkolzina, Collusion Detection in Procurement Auctions, (2013). doi:10.2139/ssrn.2221809.

[5] S.S. Padhi, P.K.J. Mohapatra, Detection of collusion in government procurement auctions, J. Purch. Supply Manag. 17 (2011) $207-221$.

[6] A. Foremny, H. Anysz, The collusion detection in public procurements - selected methods applied for the road construction industry in Poland, in: Accept. Manuscr. 2nd Balt. Conf. Students Young Res. BalCon, MATEC Web of Conferences, Gdańsk, 2018. doi:10.13140/RG.2.2.16082.04807.

[7] H. Anysz, A. Foremny, J. Kulejewski, Estimating potential losses of the client in public procurement in case of collusion utilizing a MLP neural networks, Tech. Trans. 111 (2014) 105-118. doi:10.13140/2.1.2409.6321.

[8] A. Foremny, H. Anysz, J. Kulejewski, The comparison of ANN classifier to the neuro-fuzzy system for a collusion detection in the tender procedures in the road construction sector, in: Accept. Manuscr. 3rd World Multidiscip. Civ. Eng. Plan. Symp., Prague, 2018.

[9] A. Foremny, Review of collusion and bid rigging detection methods in the construction industry, in: Accept. Manuscr. 7th Creat. Constr. Conf., Ljubjana, 2018.

[10] Organisation for Economic Co-operation and Development (OECD), Ex Officio Cartel Investigations And The Use Of Screens to Detect Cartels, 2013. http://www.oecd.org/daf/competition/exofficio-cartel-investigation-2013.pdf.

[11] W.H. Boshoff, R. Van Jaarsveld, Recurrent collusion : Cartel episodes and overcharge in the South African cement market.

[12] The Office of Competition and Consumer Protection, Decision DOK-48/07 through the change of concerned document on penalising Ożarów Group with a fine of PLN 2 million for the lack of coopeeration during the control performed May 31st - June 2nd, $2006,2007$.

[13] The Office of Competition and Consumer Protection., Decision DOK-7/09 on price fixing and other terms of portland cement sales, 2007.

[14] S. Wojciech, V. Krasnowska-Sałustowicz, Collusion just next to Białystok, Forbes. (2013).

[15] E. Sadowska-Dubicka, There was no bid rigging during the construction of the national road 8 Jeżewo-Białystok, (2015).

[16] Supreme Court, Order of the Supreme Court of January 18th, 2017, ref. II KK 324/16: dismissal of cassation in the collusion suspicion in A4 Radymno - Korczowa construction tender, 2017.

[17] W. Surmacz, V. Krasnowska-Sałustowicz, It was just recorded by the Agency, my dear..., Forbes. (2013).

[18] W. Surmacz, V. Krasnowska-Sałustowicz, Business of the lifetime on S8, Forbes. (2013).

[19] M. Jałoszewski, Of a roadworker, who only helped the colleagues. The trial of managers accussed of road collusion, Gaz. Wybor. (2014).

[20] General Directorate for National Roads and Motorways will withdraw the lawsuit against price collusion regarding S8 road construction, (2017) http://www.zamowienia-publiczne.lex.pl/czytaj/-/artykul/gddkia-wycofa-pozew-w-sprawie-zmowy-cenowej-przy-budowiedrogi-s8?refererPlid=5251680.

[21] Andrzej Skórka, The motorway exit under investigators' scrutiny, (2013).

[22] Judgment in the Tarnów bid rigging case. Public officials among the suspects, (2016). http://www.portalsamorzadowy.pl/prawo-ifinanse/wyroki-w-sprawie-zmowy-przetargowej-w-tarnowie-wsrod-oskarzonych-urzednicy,80524.html

[23] Bid rigging on the A4 junction contruction. One of the companies admits to fraud, Gaz. Wybor. (2015).

[24] General Directorate for National Roads and Motorways website. http://www.gddkia.gov.pl/ .

[25] K. Majszyk, Was there a price collusion or not? Investigators unfreeze road construction. (2016).

[26] The Office of Competition and Consumer Protection, The Office of Competition and Consumer Protection brings down the wood-based panels cartel, (2017).

[27] The Office of Competition and Consumer Protection, The sentence of the decision nr DOK-3_2017 regarding the collusion of particle and fiberboards producers, 2017.

[28] The Office of Competition and Consumer Protection imposes fines for price collusion on the construction market, Dz. Bałtycki. (2007).

[29] The Office of Competition and Consumer Protection: Price collusion on the construction market. https://www.money.pl/gospodarka/wiadomosci/artykul/uokik;zmowa;cenowa;na;rynku;budowlanym,144,0,310160.html

[30] H.W. Friederiszick, F.P. Maier-Rigaud, The Role of Economics in Cartel Detection in Europe, Conf. New Polit. Econ. 24 (2007) $179-196$. doi:10.1628/186183407785978404. 